\title{
Influence of protein level in the diet on performance of Polish Lowland lambs
}

\author{
J Pajak, T Zebrowska, B Skiba \\ Polish Academy of Sciences, The Kielanowski Institute of Animal Physiology \\ and Nutrition, 05-110 Jablonna, Poland
}

Fattening performance of Polish Lowland lambs from weaning at 90 days of age to $40 \mathrm{~kg}$ live weight was studied. Male and female lambs (64 males and 64 females in groups of 8 animals each) were fed according to Polish standards (1993, Nutrient Requirements of Cattle and Sheep, Traditional System, Instytut Zootechniki Krakow) or on diets with protein level reduced to 100 and $95 \mathrm{~g}$ PDI in DM (male and female, respectively). Daily rations were composed of meadow hay $(20 \%)$ and concentrate $(80 \%)$, and rations dry matter was calculated according to the equation $\mathrm{DM}_{\mathrm{kg}}=\left(41.9 \times \mathrm{BW}_{\mathrm{kg}}-217.6\right) \times 0.0011$. To calculate the content of intestinal digestible protein the values of effective protein degradability estimated on 3 adult sheep were used.

Energy value of experimental rations was similar (1.02 vs 1.07 UFV) but crude protein content in DM of protein restricted rations was lower than those of Polish standards, and this probably the reason of differences in lamb growth rates. Both the male and female lambs grew significantly better $(P \leq 0.05)$ when fed according the Polish standards than on protein restricted rations.

The rate of growth of female fed on protein restricted rations was slower in the middle and last fattening period. The growth rate of male was similar regardless of the rations but at the end of fattening period those fed on lower protein rations grew significantly less than on Polish standards. Utilization of DM, PDIE and UFV by both male and female lambs was worse $(P \leq 0.01)$ when fed on low protein ration than on Polish standards.

\section{Feeding standards}

PDIN in DM intake $(\mathrm{g} / \mathrm{kg})$

PDIE in DM intake $(\mathrm{g} / \mathrm{kg})$ Initial body weight $(\mathrm{kg})$

Total gain $(\mathrm{kg})$

Daily live-weight gain (g) DM utilization ( $\mathrm{kg} / \mathrm{kg}$ gain) PDIN utilization ( $\mathrm{g} / \mathrm{kg}$ gain) PDIE utilization ( $\mathrm{g} / \mathrm{kg}$ gain) UFV utilization per $\mathrm{kg}$ gain

Polish
134
115
$19.4 \pm 2.6$
$19.7 \pm 2.9$
$258 \pm 39$
$4.3 \pm 0.3$
$570 \pm 38$
$489 \pm 37$
$4.5 \pm 0.3$

Male

"P $\leq 0.05$ *P $\leq 0.01$

\begin{tabular}{|c|c|}
\hline \multicolumn{2}{|c|}{ Female } \\
\hline Polish & Restricted \\
\hline 134 & 95 \\
\hline 115 & 142 \\
\hline $18.4 \pm 2.3$ & $18.4 \pm 2.3$ \\
\hline $18.4 \pm 2.1$ & $15.5 \pm 2.1$ \\
\hline $204 \pm 35$ & $139 \pm 34^{*}$ \\
\hline $5.0 \pm 0.6$ & $7.0 \pm 0.3^{*}$ \\
\hline $675 \pm 72$ & $663 \pm 33$ \\
\hline $579 \pm 64$ & $995 \pm 40^{\circ *}$ \\
\hline $5.4 \pm 0.6$ & $7.1 \pm 0.3^{* *}$ \\
\hline
\end{tabular}

